ARIADNA; CULTURA, EDUCACIÓN Y TECNOLOGÍA. VOL. I, NÚM. 1, JUL. 2013 - HTPP://ARIADNA.UJI.eS

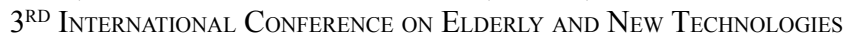

PP. 25-32 - DOI: HTTP://DX.DOI.ORG/10.6035/ARIADNA.2013.1.5

\title{
Elderly teachers and ICT - opportunities for active aging in the profession
}

\author{
Nadezhda Kaloyanova \\ Faculty of Social Science, Prof. Assen Zlatarov University, Bulgaria \\ kaloyanowa_n@yahoo.com \\ Tinka Ivanova \\ Faculty of Social Science, Prof. Assen Zlatarov University, Bulgaria
}

\begin{abstract}
In focus of the proposed development is digital competence of teachers over 50 years of age, here defined as elderly teachers. In terms of research, digital competence is understood as a key competence according to the European Reference Framework for Lifelong Learning. It is considered as an integrated and acknowledged part of teacher's professional competencies which are in dynamic relationship with its status-role profile. 400 elderly teachers (over 50 years of age) of different levels of education are studied. The study was conducted between 2010-2012 in three phases. The first phase is part of a major survey of 1000 respondents to the dynamics of the teaching profession and described the willingness of elderly teachers to integrate ICT in their professional activity. The second phase aims to derive a model of competency-role profile of elderly teachers by ІСт integration in education. The model is derived by questionnaire and formed the basis of respondent's perceptions of the bilateral relationship "digital competence and teachers professional roles". In the third phase the study is deepened in establishing the attitudes of elderly teachers to use ICT in their daily and professional lives. The used method was focus group. The conclusions are that elderly teachers do not have digital competence as a necessary part of modern teachers' competency-role profile. The conclusion concerns the need to rethink approaches to training and lifelong learning to ICT especially for elderly teachers. The general conclusion is that attention should be directed toward training comprehensive competency-role complexes instead of the formation of fragmented knowledge and skills.
\end{abstract}

Keywords: elderly teachers, digital competence, professional competence, teachers' competence-role profile

\section{Resumen}

En el centro de la propuesta de desarrollo está la competencia digital de los docentes de más de 50 años de edad, denominados aquí profesores mayores. En cuanto a la investigación, la competencia digital se entiende como una competencia clave de acuerdo con el marco de referencia europeo para el aprendizaje permanente. Se considera como una parte integrante y reconocida de las competencias profesionales de los profesores que están en relación dinámica con su perfil de estatus-rol. Se estudian 400 profesores de edad avanzada (de más de 50 años de edad) de diferentes niveles de educación. El estudio fue realizado entre 2010-2012 en tres fases. La primera fase forma parte de un importante estudio de 1000 profesores que respondieron a la dinámica de la profesión docente y se describe la disposición de los profesores mayores para integrar las TIC en su actividad profesional. La segunda fase tiene como objetivo obtener un modelo de perfil de competencias del rol de los docentes mayores al integrar las Tic en la educación. El modelo se deriva mediante un cuestionario y es la base de la percepción del encuestado sobre la relación bilateral competencia digital y roles 
de los profesores profesionales. En la tercera fase se profundiza en el establecimiento de las actitudes de los profesores mayores a utilizar las TIC en su vida cotidiana y profesional. El método utilizado fue el grupo focal. Las conclusiones son que los profesores mayores no tienen una competencia digital como parte necesaria del perfil de competencias del rol de los profesores modernos. La conclusión se refiere a la necesidad de repensar los enfoques para la formación y el aprendizaje permanente de las Tic, especialmente para los profesores mayores. La conclusión general es que la atención debe orientarse hacia la formación integral del rol-competencia complejo en lugar de la formación de conocimientos y habilidades fragmentadas.

Palabras clave: profesores mayores, competencia digital, competencia profesional, perfil de competencias del rol de los profesores.

\section{Introduction}

Bulgarian educational situation is reflecting the scale of the European population aging trend. According to the current conditions, teachers over 50 years of age and teaching experience of 25 years for women and 30 years for men are identified as teaching specialists in pre-retirement and retirement age, i.e. elderly teachers ( $\$ 5$ of Final Provisions of Social Security Code). According to the National Statistical Institute, during the academic year 2010-2011, elderly teachers represent 39.92\% of teachers' population in Bulgaria, and $48.95 \%$ of them are over 55 years of age (Table 1).

The so described situation refers to a sustainable aging trend among teachers' profession. Table 1 shows that for the past 10 years in Bulgaria the share of young teachers has rapidly decreased and the share of elderly teachers has increased.Table 1 also indicates a declination in Bulgaria demographic conditions. In the specified 10 years period, teachers' population has decreased by almost $26 \%$. The demographic breakdown is most obvious in small towns and villages where students and especially schools are few and where observations show concentrated presence of senior teachers.
On the other hand, analysis based on statistic data alarm that up to eight years, one third of teachers are going to leave the system due to reaching the age of retirement or reaching the required length of service for pension.

In response to these trends registered in Bulgaria, a pension reform has been started. First measures include increasing the age of retirement by 4 months each year until reaching 63 years of age for women and age 65 for men. Another measure is the abolition of Art. 328, Al. 10 from the Labour Code, which allows employees to choose whether to retire or to remain in employment after the acquisition of pension rights.

The change in regulations and worsened socioeconomic conditions create serious prerequisites for long-term stay of teachers in the profession. Currently most of the retired teachers reintegrate in different parts of the education system, most often their presence is noticed in the field of private education - private schools, groups for school training, day centres, and in public schools as substitute teachers.

The quoted data indicate that the professional competence of elderly teachers (over 50 years of

Table 1. Teachers' population state during the period 2000-2011

\begin{tabular}{|r|r|r|r|r|r|r|r|r|r|r|}
\hline & All & over 25 & $25-29$ & $30-34$ & $35-39$ & $40-44$ & $45-49$ & $50-54$ & $55-59$ & $\begin{array}{c}60 \text { a. } \\
\text { more }\end{array}$ \\
\hline $2000 / 2001$ & 63752 & 1658 & 6590 & 9761 & 11046 & 12229 & 10571 & 7531 & 3744 & 622 \\
\hline $2010 / 2011$ & 47230 & 266 & 1294 & 3288 & 6139 & 8351 & 9040 & 9717 & 7559 & 1576 \\
\hline
\end{tabular}


age) determines in a substantial degree the quality of secondary education in the country. The presence of digital competence as an integrative part of the professional competence of teachers is an important indicator for that.

\section{Theoretical Background}

In the European Reference Framework for Key Competence for Lifelong Learning, competences are defined as "...a combination of knowledge, skills and attitudes appropriate to the context". Key competences "are those which all individuals need for personal fulfilment and development, active citizenship, social inclusion and employment". Professional competences are defined as a combination of knowledge, skills and abilities that workers and scientists/researchers in a field are required to have (European Reference Framework, 2007: 5).

Interpreting the two concepts within one unified theoretical framework leads to the conclusion that the integration of key competencies in the professional competence of different professionals produces qualitatively new competencies that are specific for the particular professions. In terms of the teaching profession, competence, specified by the integration of digital competence in teachers' professional competencies could be named a "professional competence to integrate ICT in education" and should include:

- Digital competence as a key competence with the following contents: “...the confident and critical use of Information Society Technology (IST) for work, leisure and communication. It is underpinned by basic skills in ІСт: the use of computers to retrieve, assess, store, produce, present and exchange information, and to communicate and participate in collaborative networks via the Internet" (European Reference Framework, 2007: 7).

- Specific professional competencies for the implementation of the latest educational approaches (constructivist, connectionist, activist, etc.), suggesting the use of ICT in the learning process.

In the modern dynamic educational situation professional competence to integrate ICT in education is one of many basic, universal competencies necessary for teachers to achieve efficiency in the profession. Referring to the role theory in social psychology, our research shows that accumulating professional competencies of modern teacher fail to put into practice sufficiently effective role scenarios (Jonev, 1996). The last causes stress, which is a prerequisite for worsening the quality of the learning process. Therefore, based on role theory, an up-to-date concept of the teaching profession is proposed. The initial assumption is the perception of the teaching profession as a weakly structured integrity, which main structural component is the relation "status-roles-functions". It assumes that "status" is a socio-personal aspect of the teacher in the profession, filled with professional roles. The role, in its turn, is realized through reasonable professional functions. Status, roles and functions are in dynamic, nonlinear relations, depending on the particular pedagogical situation. Since for the

Table 2. Respondents' distribution from a sociological survey by age and experience

\begin{tabular}{|l|r|r|r|r|r|}
\hline Age & \multicolumn{1}{|c|}{$\begin{array}{c}\text { Pedagogical ex- } \\
\text { perience } \\
\text { years }\end{array}$} & $\begin{array}{c}\text { Up to } 20 \\
\text { years }\end{array}$ & $\begin{array}{c}\text { Up to } 30 \\
\text { years }\end{array}$ & \multicolumn{1}{c|}{$\begin{array}{c}\text { Over } 31 \\
\text { years }\end{array}$} & Total \\
\hline Up to 24 & $5 \%$ & $0 \%$ & $0 \%$ & $0 \%$ & $5 \%$ \\
\hline From 25 to 35 & $10.2 \%$ & $3.0 \%$ & $3 \%$ & $0 \%$ & $13.5 \%$ \\
\hline From 36 to 45 & $1.1 \%$ & $19.9 \%$ & $4.8 \%$ & $3 \%$ & $30.2 \%$ \\
\hline From 46 to 55 & $4 \%$ & $4 \%$ & $2.1 \%$ & $11.4 \%$ & $14.3 \%$ \\
\hline Over 55 & $17.3 \%$ & $28.3 \%$ & $31.5 \%$ & $22.9 \%$ & $100.0 \%$ \\
\hline Total & & & & & $41.5 \%$ \\
\hline
\end{tabular}


implementation of a particular professional role it is necessary to master competences and the competences themselves suggest the "entry" in certain roles, roles and competencies form the specific competency-role models, which are subject of research and development (Ivanova, 2010; Kaloyanova, 2010a; Kaloyanova, 2010b; Kaloyanova \& Ivanova, 2010).

\section{Research}

According to the theoretical assumptions, the focus of the proposed study is the digital competence of teachers over 50 years of age as a part of the professional competence of teachers to integrate ICT in education. The dynamics of the relationship between digital competence and status-role profile of the teacher has been monitored through his specific competency-role model. 400 teachers, over 50 years of age and from different levels of education, were examined. The study is presented in three parts. Each part is an extract from larger studies conducted in 2010-2012, but here they are analyzed in the context of interest.

First is an extract from a sociological survey on the dynamics of the teaching profession conducted in 2011 among 1000 respondents. At this stage, the trends of the willingness of elderly teachers to integrate ICT in their professional activity are outlined. Three questions of sociological inquiry are analyzed:

- Which of the following responsibilities put unnecessary strain on you? Respondents choose among ten statements from which two are related to ICT in education: "The use of ICT" and "Electronic textbooks". The respondents may indicate more than one statement as referring to them.

- If you were invited to participate in a training course, what topics would you suggest?

- In what kind of training course would you participate?

These two last questions are open. The categories for the analysis of both questions are determined by frequency content analysis of responses of all respondents. From the answers to the question: "If you were invited to participate in a training course,
Table 3. Distribution of respondents' reply to the question "Which of the following responsibilities puts unnecessary strain on you?"

\begin{tabular}{|l|l|c|c|}
\hline \multicolumn{2}{|l|}{$\begin{array}{r}\text { Pedagogic } \\
\text { experience }\end{array}$} & $\begin{array}{c}\text { Over } \\
31 \\
\text { Age }\end{array}$ & \multirow{2}{*}{ Total } \\
\cline { 1 - 2 } $\begin{array}{l}\text { The use of } \\
\text { ICT }\end{array}$ & From 46 to 55 & $3.41 \%$ & \multirow{2}{*}{$9.26 \%$} \\
\cline { 2 - 3 } $\begin{array}{l}\text { Electronic } \\
\text { textbooks }\end{array}$ & From 46 & $5.85 \%$ & \\
\cline { 2 - 3 } Over 55 & $7.80 \%$ & \multirow{2}{*}{$10.72 \%$} \\
\hline
\end{tabular}

what topics would you suggest?", six categories can be defined, among which is the category: "ICT in training /education". This category includes three subcategories: "Working with computer/computer literacy", "E-learning content", "Electronic training tools".

From the answers to the question: "In what kind of training course would you participate?" eight categories can be defined among which is the category: "Information Technology".

For the purposes of this study the results of teachers meeting the profile "elderly teachers" are summarized. Respondents are over 46 years of age and have more teaching experience than 31 years of. These respondents are 228 and represent $22.9 \%$ of all 994 surveyed and indicated their experience and age in the questionnaire (Table 2).

The data from the first phase of the study were processed using sPss ${ }^{\mathrm{TM}}$ Statistics Data Editor 17.0 in percentage and by using cross-data (Crosstabs) in three areas.

In the second phase, a model of competencyrole profile of elderly teachers by ICT integration in education is presented. The model is derived by questionnaire and formed on the basis of respondent's perceptions of the bilateral relationship "digital competence and teachers professional roles". Teachers match 28 previously indicated professional roles with 8 key competences for lifelong learning. By being asked additional questions, respondents are given the opportunity to explain their choice. The statistical methods of analysis are relatively share distribution, rank and frequency scale. The study was conducted gradually in 2010 
Table 4. Distribution of the respondents' responses between the subcategories of the category "ICT in education/training"

\begin{tabular}{|c|c|c|c|}
\hline \multicolumn{2}{|r|}{$\begin{array}{r}\text { Pedagogical } \\
\text { experience }\end{array}$} & $\begin{array}{c}\text { Over } \\
31 \\
\text { years }\end{array}$ & Total \\
\hline \multirow{2}{*}{$\begin{array}{l}\text { Working with } \\
\text { computer/ } \\
\text { computer } \\
\text { literacy }\end{array}$} & $\begin{array}{c}\text { From } 46 \text { to } \\
55\end{array}$ & $20 \%$ & $55 \%$ \\
\hline & over 55 & $35 \%$ & \\
\hline \multirow{2}{*}{$\begin{array}{l}\text { E-learning } \\
\text { content }\end{array}$} & $\begin{array}{c}\text { From } 46 \text { to } \\
55\end{array}$ & $0 \%$ & $20 \%$ \\
\hline & over 55 & $20 \%$ & \\
\hline \multirow{2}{*}{$\begin{array}{l}\text { Electronic } \\
\text { training tools }\end{array}$} & $\begin{array}{c}\text { From } 46 \text { to } \\
55\end{array}$ & $0 \%$ & $25 \%$ \\
\hline & over 55 & $25 \%$ & \\
\hline Total & & & $100 \%$ \\
\hline
\end{tabular}

among more than 400 teachers. For the purposes of this study, the results of 100 teachers of over 50 years of age are presented.

In the third phase the study is getting more detailed in establishing the attitudes of elderly teachers to use ICT in their daily lives. The study was conducted from 2011 to 2012 among 72 elderly teachers using the focus group method. Teachers, divided into 6 groups of 12 people, the following issues were discussed:

- What is your attitude towards the use of ICT in education?

- For what purposes do you usually use ICT?

- For what purposes do you usually use ICT in your professional activities?

Data are summarized by qualitative and quantitative content-analysis based on the most common responses.

\section{Results}

Part I: Empirical thesis regarding the willingness of elderly teachers to integrate ICT in their professional activity.
The general attitude of elderly teachers toward ICT has been derived from the answer to the question: "Which of the following responsibilities puts unnecessary strain on you?" 207 elderly teachers replied to this question, and this is almost $90 \%$ respondents from the study group. The statement "use of ICT" is indicated by $9.26 \%$ of the respondents as the majority of them are teachers over 55 (Table 3).

Similar results are also observed concerning the statement "E-text books". The response rate for this question is a little bit over $10 \%$. The observations show that among elderly teachers, working with Etextbooks puts additional strain to those who are under 55 years of age (Table 3). 111 elderly teachers replied to the question, when asked "If you were invite to participate in a training course, what topics would you suggest?", which is about $49 \%$ respondents from the study group. $18 \%$ of them would suggest topics related to ICT in teaching/ education. According to the three subcategories of the category of ICT in teaching/education, elderly teachers would prefer topics related to basic competences in this field. This trend is particularly true for teachers over 55 years of age (Table 4).

The question "In what kind of training course would you participate?" received a response from 107 elderly teachers, which is $47 \%$ of participants

Table 5. Absolute and relative frequency of roles in the range of digital competence

\begin{tabular}{|c|r|r|r|}
\hline $\begin{array}{l}\text { Number spec- } \\
\text { ified roles }\end{array}$ & f & P & Q \\
\hline 0 & 5 & 0.050 & 0.050 \\
\hline 1 & 20 & 0.200 & 0.250 \\
\hline 2 & 17 & 0.170 & 0.420 \\
\hline 3 & 26 & 0.260 & 0.680 \\
\hline 4 & 9 & 0.090 & 0.770 \\
\hline 5 & 0 & 0.000 & 0.770 \\
\hline 6 & 10 & 0.100 & 0.870 \\
\hline 7 & 3 & 0.030 & 0.900 \\
\hline 8 & 5 & 0.050 & 0.950 \\
\hline 9 & 4 & 0.040 & 0.990 \\
\hline 10 & 1 & 0.010 & 1 \\
\hline & 100 & & \\
\hline
\end{tabular}




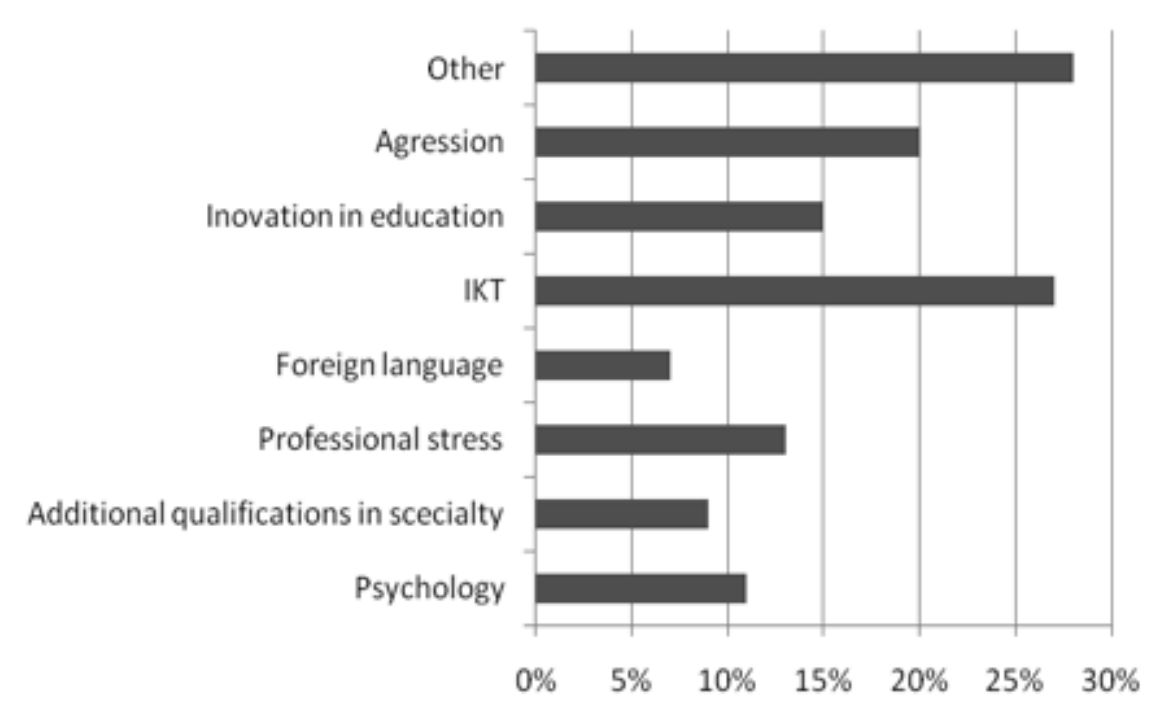

Figure 1. Distribution of respondents' answers to the question "In what kind of training course would you participate?"

in the study group. $27 \%$ of them would take part in a course on ICT. This is the second most preferred qualification by elderly teachers (Figure 1).

The results from the first part of the study bring controversial questions about the willingness of elderly teachers to integrate ICT in their professional activity. It was empirically proven that the use of ICT in education does not bring tension on elderly teachers.

This proof, supported by the other results from this part of the survey, raises two opposing thesis:

- Elderly teachers recognize digital competence as a part of their professional competence as less than $9 \%$ of all subjects would offer topics for ICT in education qualification and only $12 \%$ would participate in courses on ICT.

- Elderly teachers do not recognize digital competence as a part of their professional competence and ignore new technologies in their professional activities, since few of them wish to qualify in the field of ICT, and those who have expressed such a desire need basic training in this area.

The so described thesis will be further clarified in the rest of the survey.

Part II: Empirical thesis on competence-role profile of elderly teachers in integrating technology in education.
The model includes two interdependent aspects:

- Role "content" of digital competence - the perception of elderly teachers of the quantity and types of roles performed by teachers in order to integrate ICT in education.

- The significance of digital competence for the implementation of the derived professional roles.

The validation of teachers' model regarding the quantitative roles in the volume of digital competence is done by defining the absolute frequency $(F)$ and relative frequencies $(\mathrm{P}, \mathrm{Q})$ of the roles indicated (Table 5).

Data show that the biggest share (60\%) from the respondents think that digital competence requires entering in no more than three professional roles.

According to the respondents, these roles are:

1. Source of information - it has been indicated by 32 respondents, and the average rank of indication is 2.34 , i.e. it has been placed between second and third place on the list. Teachers associate this role with the following functions: searching and presenting information, guiding students through the available information, the providing information sources in education.

2. Innovator - this role has been appointed by 27 respondents, and the average rank of indication is 2.23 , i.e. it has also been placed between second and third place on the list. This role according to teachers suggests the following functions: using new technologies in education, working with foreign languages.

3. Expert - this role has been appointed by 18 respondents, and the average rank of indication is 4.12 , i.e. it has been placed between fourth and fifth place on the list. This role has the following functions in teachers' perceptions: providing expert assistance to students, high level of competence in its field. 
According to the understanding of elderly teachers, the implementation of these professional roles requires the following key competencies, rated by importance:

1. Source of information: cultural competencies, social and civil competences, communicative competence in mother language, communicative competence in foreign language, digital competence, mathematical competence and basic competences in the natural sciences and technologies.

2. Innovator: initiative and entrepreneurship, cultural competencies, digital competence, communicative competencies in foreign languages, mathematical competence and basic competences in the natural sciences and technologies, communicative competencies in mother tongue.

3. Expert: cultural competencies communicative competencies in foreign language, communicative competencies in mother language, digital competence, initiative and entrepreneurship, mathematical competence and basic competences in natural sciences and technologies

The results from the second part of the study provide partial confirmation of the thesis that there is insufficient digital competence as part of the professional competence of elderly teachers because:

- The competence-role profile of elderly teachers about integrating ICT is fragmented. It is based on three roles in which the digital competence is at the lowest positions.

- Two of the three roles in the model source of information and expert, are traditional roles for direct mentoring. Teachers recognize their traditional functions, which confirm teacher's leading position in training. This means that elderly teachers rationalize digital competence through its role-scenario stereotype, i.e. it cannot be adequately acknowledged.

\section{Part III: Empirical thesis on the willingness of elderly teachers to use ICT in their daily lives.}

The results from the discussion on ICT use in daily life of elderly teachers are interpreted in relation to the presence or lack of additional qualification in the field of information technologies. This is nec- essary in order to trace the overall attitude of respondents towards ICT. In a sample of 72 teachers, all of them have received training on basic computer skills. Only 18 (25\%) of them have the training upgraded or updated professionally. Others have developed skills based on personal experience.

The following opinions have emerged from the discussion on particular topics:

1. Attitude towards the use of ICT in education:

- It takes a lot of time, effort and resources that teachers and educational institutions usually do not have.

- Often students, especially in higher grades, are more competent than the teacher and he loses authority.

- In certain subjects, the use of ICT is inappropriate - for example lessons in literature, language and arts.

- ICT are necessary, but not the most important in education - no one can replace the teacher;

- The use of ICт makes students indolent in studying.

2. Usual use of ICT:

- To search for information and entertainment on the Internet.

- To communicate with colleagues, relatives, friends: mostly using Skype and e-mail.

3. Using ICT in professional activities:

- Using multimedia presentations on educational content but preferably in ready form, because they don't have enough skills to make them.

- Searching for additional information on the Internet.

- Text editing.

The results from the focus group confirm the following empirical thesis:

- Regardless of the training level in using ICT, elderly teachers feel stressed and burdened by their application in professional activities.

- Elderly teachers feel threatened by ICT, especially in terms of their authority and position in teaching. 
- In their daily life, teachers use ICт for trivial purposes, almost without relation to the profession.

- Elderly teachers see the place of ICT in education primary as a tool for obtaining and presenting information.

\section{Conclusions}

The study proves, though only in a certain aspect, the limited capability of Bulgarian teachers for active aging in the profession. Empirical thesis exposed in different parts of this study point towards digital literacy failure as part of the professional competence of elderly teachers, which is a prerequisite for worsened quality of education. Consciously or not, teachers resist the entry of ICT in their professional and personal life. Their resistance is expressed in the tendency to ignore ICT in professional activities or in their trivial use both in professional and personal life. This is due to perceived vulnerability of their own authority and professional position, a sense of incompetence, inability to overcome status-role stereotypes. This study confirmed that elderly teachers possess the basic knowledge and skills in ICT, but do not have the motivation to develop or implement them. What elderly teachers are lacking for their knowledge and skills to turn into competence is the most essential part of any competence - attitude towards ICT as an integral part of the status-role complex, especially in modern life. In its scale, the study confirms that the classification of elderly teachers should be based on approaches supporting active aging, and not on specialization and strictly subject-orientation. In qualification activity, elderly teachers have to overcome their status-role stereotypes, expand their role scenarios and receive psychological support for realizing themselves as a dynamic part of a dynamic educational situation.

\section{References}

Ivanova, T. (2010). Teachers professional roles in contemporary educational situation. Dialogue between generations and social structures through the school institution: 143-149.

Jonev, S. (1996). Social Psychology. T.2. Communication. Person. Sofia: SOFI-R.

Kaloyanova, N. (2010a). Some untypical roles of contemporary teacher. Challenges facing higher education and research in a crisis 1: 254-261.

Kaloyanova, N. (2010b). Key competences and teachers' professional roles in technology integrating education. Education and technology 1: 58-61.

Kaloyanova, N. \& Ivanova, T. (2010). Key competences and teachers profesional roles. Management and education, Vol. 6(1): 248-254.

The European Framework for Key Competences for Lifelong Learning. (2007). Luxembourg: Office for Official Publications of the European Communities. 